University of Nebraska - Lincoln

DigitalCommons@University of Nebraska - Lincoln

Faculty Papers and Publications in Animal

Science

Animal Science Department

2010

\title{
Effect of dietary crude protein source on hormone and follicle characteristics in beef heifers
}

\author{
J. L. Martin \\ University of Nebraska-Lincoln \\ D. M. Larson \\ University of Nebraska-Lincoln \\ H. L. Stroh \\ University of Nebraska-Lincoln \\ Andrea S. Cupp \\ University of Nebraska-Lincoln, acupp2@unl.edu \\ Richard N. Funston \\ University of Nebraska-Lincoln, rfunston2@unl.edu
}

Follow this and additional works at: https://digitalcommons.unl.edu/animalscifacpub

Part of the Animal Sciences Commons

Martin, J. L.; Larson, D. M.; Stroh, H. L.; Cupp, Andrea S.; and Funston, Richard N., "Effect of dietary crude protein source on hormone and follicle characteristics in beef heifers" (2010). Faculty Papers and Publications in Animal Science. 750.

https://digitalcommons.unl.edu/animalscifacpub/750

This Article is brought to you for free and open access by the Animal Science Department at DigitalCommons@University of Nebraska - Lincoln. It has been accepted for inclusion in Faculty Papers and Publications in Animal Science by an authorized administrator of DigitalCommons@University of Nebraska - Lincoln. 


\title{
Effect of dietary crude protein source on hormone and follicle characteristics in beef heifers ${ }^{1}$
}

\author{
J. L. Martin, ${ }^{*} \dagger$ D. M. Larson, $\dagger$ H. L. Stroh, ${ }^{*} \dagger$ A. S. Cupp, ${ }^{*}$ and R. N. Funston $* \dagger^{2}$ \\ *University of Nebraska, Lincoln 68583-0908; \\ and †University of Nebraska West Central Research and Extension Center, North Platte 69101
}

\begin{abstract}
Ground, raw soybeans (SB), or dried distillers grain plus solubles (DDGS) were utilized in heifer development diets to determine the effect of dietary fat and protein source on hormone and follicle characteristics and ADG. The experiment was conducted over 2 yr with 100 June-born heifers (199 $\pm 2 \mathrm{~kg}$ initial BW, $\mathrm{n}=50$ per yr). The experimental periods were 157 and $207 \mathrm{~d}$ in yr 1 and 2, respectively. Heifers were provided a dietary supplement (DM basis) of $1.23 \mathrm{~kg}$ of SB and $0.40 \mathrm{~kg}$ of corn or $1.65 \mathrm{~kg}$ of DDGS between weaning and breeding. Estrus was synchronized with 2 injections of $\mathrm{PGF}_{2 \alpha} 14 \mathrm{~d}$ apart. Dominant follicles were measured and aspirated via transvaginal ultrasonography $60 \mathrm{~h}$ after the second $\mathrm{PGF}_{2 \alpha}$ injection. Heifers were exposed to bulls beginning $14 \mathrm{~d}$ after aspiration for 45
\end{abstract}

d. Heifer ADG was greater $(P=0.02)$ for DDGS heifers in yr 1 , but was similar $(P=0.47)$ in yr 2 . However, there was no difference $(P=0.35)$ in final $\mathrm{BW}$ in either year. There was no difference $(P \geq 0.67)$ in follicle size, follicle hormone concentrations, or pregnancy rate $(88 \%)$ between yr 1 and 2. Serum estrogen at 48 or $60 \mathrm{~h}$ after $\mathrm{PGF}_{2 \alpha}$ injection were similar $(P \geq 0.91)$; however, $\mathrm{LH}$ at $60 \mathrm{~h}$ in yr 2 tended to be greater $(P=0.07)$ for DDGS heifers. The percentage of heifers experiencing an LH surge 48 and $60 \mathrm{~h}$ after $\mathrm{PGF}_{2 \alpha}$ injection was not affected $(P \geq 0.40)$ by treatment. Calf production was not affected $(P \geq 0.20)$ by developmental diet. In summary, DDGS and SB have similar effects on hormone and follicle characteristics at the inclusion rates used in these studies.

Key words: fertility, heifer development, protein supplement

(0)2010 American Society of Animal Science. All rights reserved.

J. Anim. Sci. 2010. 88:937-942 doi:10.2527/jas.2009-2236

\section{INTRODUCTION}

Development of replacement heifers at growth rates sufficient to ensure that a large percentage reach or are near puberty before breeding is important for efficient beef cattle production. Supplementation of low- or medium-quality roughage diets with high-energy sources of protein can provide sufficient nutrients for economic development and successful reproductive function. Soybeans (SB) are a nutrient-dense feedstuff $(40 \% \mathrm{CP}$; $20 \%$ fat, DM basis; NRC, 1996), associated with improved reproductive function in beef heifers (Lammoglia et al., 2000) and mature cows (Wehrman et al., 1991; Ryan et al., 1992). Another economical, high-energy

\footnotetext{
${ }^{1}$ A contribution of the University of Nebraska Agricultural Research Division, supported in part by funds provided through the Hatch Act. Mention of a trade name, proprietary products, or company name is for presentation clarity and does not imply endorsement by the authors of the University of Nebraska.

${ }^{2}$ Corresponding author: rfunston2@unl.edu

Received June 22, 2009.

Accepted November 13, 2009.
}

source of $\mathrm{CP}$ from the corn milling industry is dried distillers grain plus solubles (DDGS; 30\% CP; $11 \%$ fat, DM basis; NRC, 1996). Feeding DDGS provides CP, undegradable intake protein, energy, and fat and has been reported to improve conception rates in yearling beef heifers (Martin et al., 2007). Both SB and DDGS may be beneficial to reproduction as sources of dietary fat and CP (Wiley et al., 1991; Williams and Stanko, 2000; Martin et al., 2007). Supplemental fat stimulated programmed growth of preovulatory follicles, increased total number of follicles, and increased the size of preovulatory follicles (Mattos et al., 2000). Increased size of preovulatory follicles may be due, in part, to increased concentrations of plasma LH, which stimulates the later stage of follicular growth. The ovulation of larger follicles may result in the formation of larger corpora lutea with increased steroidogenic capacity and result in greater progesterone production, which has been associated with greater conception rates. Thus, to further investigate the mechanism by which these supplements may influence reproductive outcome, the objective of this study was to determine the effects of supplemental $\mathrm{SB}$ or DDGS on hormone and follicle characteristics and $\mathrm{BW}$ gain in beef heifers. 


\section{MATERIALS AND METHODS}

Procedures and facilities for this experiment were approved by the University of Nebraska-Lincoln Institutional Animal Care and Use Committee. This experiment was conducted over $2 \mathrm{yr}$ at the University of Nebraska Gudmundsen Sandhills Laboratory near Whitman.

This experiment was replicated in 2 yr using 100 summer-born heifers $(\mathrm{n}=50$ each yr). Crossbred heifers (Red Angus $\times$ Simmental; $199 \pm 2 \mathrm{~kg}$ initial BW; 8 mo of age) were allotted by BW and randomly assigned to 1 of 4 pens per year. All heifers had ad libitum access to late-harvested Sandhills meadow hay $(\mathrm{CP}=6.2$ and $8.8 \%$ for yr 1 and 2 , respectively). In each year, 2 pens of heifers were supplemented daily with $1.23 \mathrm{~kg}$ of ground SB mixed with $0.40 \mathrm{~kg}$ of ground corn $(31 \%$ CP, $17.1 \%$ fat, DM basis) per heifer and 2 pens of heifers were supplemented with $1.65 \mathrm{~kg}$ of DDGS (31\% CP, $11.5 \%$ fat, DM basis; Chief Ethanol Fuels, Hastings, NE) per heifer daily. Supplements were approximately isocaloric. Supplement nutrient analysis was performed by standard wet chemistry procedures (Ward Laboratories, Kearney, NE). The experimental supplementation periods for yr 1 and 2 were 157 and $207 \mathrm{~d}$, respectively, continuing through follicle aspiration.

Blood samples (5 $\mathrm{mL}$ via coccygeal venipuncture) were collected at 10-d intervals before and during the feeding period to determine pubertal status. Blood samples were stored at $4^{\circ} \mathrm{C}$ for serum separation by centrifugation $\left(1,300 \times g\right.$ for 20 min at $\left.4^{\circ} \mathrm{C}\right)$ within 24 h. Serum samples were stored at $-20^{\circ} \mathrm{C}$ for subsequent analysis. Serum progesterone concentrations of $>1 \mathrm{ng} /$ $\mathrm{mL}$ were considered indicative of luteal activity. Body weights were measured at the time of blood collection and at the end of the feeding period. Estrus was synchronized with 2 injections of $\mathrm{PGF}_{2 \alpha} 14 \mathrm{~d}$ apart. Sixty hours after the second injection, the largest (dominant) follicles (DF) were measured and aspirated using an ultrasound-guided transvaginal probe (Aloka $500 \mathrm{~V}$ ultrasound with a $5.0-\mathrm{MHz}$ probe; Aloka, Wallingford, $\mathrm{CT})$ with needle attachment. Blood samples $(5 \mathrm{~mL}$ via coccygeal venipuncture) were taken 48 and $60 \mathrm{~h}$ after the second injection of $\mathrm{PGF}_{2 \alpha}$ for serum $17 \beta$-estradiol $\left(\mathbf{E}_{2}\right)$ and $\mathrm{LH}$ analysis. Blood samples were stored at $4^{\circ} \mathrm{C}$ for serum separation by centrifugation $(1,300 \times g$ for 20 min at $4^{\circ} \mathrm{C}$ ) within $24 \mathrm{~h}$. Granulosa cells were harvested from aspirates, and follicular fluid (FF) samples were stored at $-80^{\circ}$ until subsequent steroid hormone analysis. Heifers were managed on native pastures with bulls for $45 \mathrm{~d}$ beginning $14 \mathrm{~d}$ after aspiration. Pregnancy was determined via transrectal ultrasonography, and BW was measured approximately $45 \mathrm{~d}$ after the end of the breeding season.

\section{RIA}

Concentrations of progesterone in serum and $\mathrm{FF}$ were determined using a solid-phase RIA kit (Coat-A-
Count, Diagnostic Products Corporation, Los Angeles, CA) without extraction as described previously (Stewart et al., 1996; Melvin et al., 1999). Inter- and intraassay CV for serum progesterone were 6.5 and $6.4 \%$, respectively. Inter- and intra-assay $\mathrm{CV}$ for $\mathrm{FF}$ progesterone were 9.0 and $9.1 \%$, respectively. Concentrations of $\mathrm{E}_{2}$ in extracted serum samples and nonextracted FF samples were determined by RIA as described by Kojima et al. (1992). Inter- and intraassay CV for FF $\mathrm{E}_{2}$ were 4.1 and $4.6 \%$ respectively; assay sensitivity was $0.01 \mathrm{pg} / \mathrm{mL}$. Inter- and intraassay $\mathrm{CV}$ for serum $\mathrm{E}_{2}$ were 10.0 and $10.0 \%$ respectively; assay sensitivity was $0.02 \mathrm{pg} / \mathrm{mL}$. Preovulatory follicles producing more $\mathrm{E}_{2}$ than progesterone were classified as estrogen-active. As granulosa cells luteinize shortly before ovulation, steroid production shifts from $\mathrm{E}_{2}$ to progesterone and the follicle is no longer $E_{2}$-active. Estrogen-activity of the DF was determined by the estrogen:progesterone ratio and $\mathrm{E}_{2}$ concentrations (ratio $\geq 1.0$ and $>100 \mathrm{ng}$ of $\mathrm{E}_{2} /$ $\mathrm{mL}$ of $\mathrm{FF}$ indicates $\mathrm{DF}$ is estrogen-active; Roberts and Echternkamp, 2003). Concentrations of LH in serum were determined in all samples by double-antibody RIA (Wolfe et al., 1989; Cupp et al., 1995) using an antiserum made against ovine LH in rabbits (TEA-RaOLH \#35), purified iodinated ovine LH (LER-1056-C2) as labeled hormone, and NIH-LH-B7 as the standard. The assay for LH was validated as follows. Serial dilutions of 4 independent bovine serum samples were assayed at volumes ranging from 50 to $200 \mu \mathrm{L}$. Assay determinations of these dilutions from each of the 4 independent samples were highly correlated $(r=0.9997)$. Three independent samples were used to determine the recovery of added LH $(15.6,31.3,62.5,125$, and $250 \mathrm{pg})$. Percent recovery from these 3 samples averaged 100.2 $\pm 5.7 \%$. Intra- and interassay CV were 2.6 and $8.2 \%$, respectively. The limit of detection of LH was $0.088 \mathrm{ng} /$ $\mathrm{mL}$ of serum under the conditions utilized. Serum LH concentrations greater than $4 \mathrm{ng} / \mathrm{mL}$ at the 48 - or $60-\mathrm{h}$ sampling were used as criteria to indicate a preovulatory LH surge had occurred (Cupp et al., 1995).

\section{Follicle Aspiration}

Before follicle aspiration, both ovaries were visualized via ultrasonography (Aloka SSD-500V) to determine location and size of the DF. The size of the largest follicle was measured across 2 dimensions and recorded. Follicle aspirations were performed using an 18-gauge stainlesssteel needle housed within a transvaginal ultrasoundguided probe (Aloka, UST-981-5). After positioning the DF opposite the vaginal wall from the needle guide, the needle was inserted through the vaginal wall and into the follicle. Follicular fluid and granulosa cells were aspirated by vacuum pressure created by a $60-\mathrm{mL}$ disposable syringe connected by plastic surgical tubing to the needle. A sterile syringe was used for each animal, and the needle and tubing were rinsed 3 times with sterile water between each aspiration. Immediately after collection, follicular aspirates were transferred into $1.5-\mathrm{mL}$ 
Table 1. Effects of supplement on heifer BW gain and pubertal status

\begin{tabular}{|c|c|c|c|c|}
\hline \multirow[b]{2}{*}{ Item } & \multicolumn{2}{|c|}{ Treatment $^{1}$} & \multirow[b]{2}{*}{ SEM } & \multirow[b]{2}{*}{$P$-value } \\
\hline & SB & DDGS & & \\
\hline $\mathrm{n}$ & 50 & 50 & & \\
\hline Initial $\mathrm{BW},{ }^{2} \mathrm{~kg}$ & 199 & 198 & 2 & 0.87 \\
\hline Midtest $\mathrm{BW},{ }^{3} \mathrm{~kg}$ & 296 & 305 & 3.0 & 0.08 \\
\hline Final $\mathrm{BW},{ }^{4} \mathrm{~kg}$ & 344 & 350 & 4.2 & 0.35 \\
\hline $\mathrm{ADG},{ }^{5} \mathrm{~kg} / \mathrm{d}$ & 0.82 & 0.87 & 0.03 & 0.03 \\
\hline Yr 1 & 0.79 & 0.90 & 0.02 & 0.02 \\
\hline Yr 2 & 0.81 & 0.78 & 0.02 & 0.47 \\
\hline Pubertal before treatment, $\%$ & 31 & 23 & 9 & 0.54 \\
\hline Pubertal before aspiration, $\%$ & 94 & 94 & 3 & 0.99 \\
\hline
\end{tabular}

conical tubes and placed on ice until centrifugation at $14,000 \times g$ for 1 min at $4^{\circ} \mathrm{C}$.

\section{Statistical Analyses}

Data were analyzed using pen as the experimental unit. Data were tested for year $\times$ treatment interactions $(P \leq 0.05)$. Individual year data will be presented where an interaction exists. Differences in BW, ADG, timing of estrus, DF diameter, and hormone concentrations in serum and $\mathrm{FF}$ were analyzed using PROC MIXED (SAS Inst. Inc., Cary, NC). Differences in synchronization, conception and pregnancy rates, cyclicity, and number of $\mathrm{E}_{2}$-active follicles were analyzed using PROC GLIMMIX of SAS. Nonsignificant $(P>0.10)$ covariates, including age and sire breed, were removed from the statistical model, and data were re-analyzed with only treatment and significant covariates remaining in the model. The random effect of pen within year $x$ treatment was included in the model.

\section{RESULTS}

Midtest BW tended to be greater $(P=0.08)$ for DDGS than SB heifers, but final BW was not different $(P=0.35$; Table 1$)$. Year of experiment (yr 1 vs. $2)$ had a significant $(P=0.03)$ effect on ADG. In yr 1 , DDGS heifers gained more BW $(P=0.02)$ than SB heifers. However, ADG was not different $(P=0.47)$ in yr 2. Treatment did not affect estrous cyclicity, nor did year $(P>0.10)$. Progesterone analysis of serum indicated $28 \%$ of heifers had achieved puberty at treatment initiation $(P=0.54)$, and $94 \%$ were pubertal at the end of the feeding period $(P=0.99)$.

There was no difference $(P=0.69)$ in DF diameter between DDGS- and SB-fed heifers (Table 2). Follicular fluid concentration of $\mathrm{E}_{2}(P=0.87)$ and progesterone $(P=0.96)$ were not affected by treatment. There was no difference $(P=0.67)$ in percentage of $\mathrm{E}_{2}$-active fol- licles between treatment groups. There were also no differences $(P>0.10)$ in $\mathrm{FF} \mathrm{E}_{2}$ or progesterone concentrations when only $\mathrm{E}_{2}$-active follicle data were analyzed. Concentrations of $\mathrm{E}_{2}$ and $\mathrm{LH}$ in serum collected $48 \mathrm{~h}$ after the second injection of $\mathrm{PGF}_{2 \alpha}$ were not affected ( $P$ $\geq 0.49$ ) by treatment (Table 3 ). There was a treatment $\times$ year interaction $(P=0.04)$ for $\mathrm{LH}$ concentrations at $60 \mathrm{~h}$, where SB and DDGS heifers had similar $(P=$ $0.35)$ serum LH concentrations in yr 1 (5.83 vs. $3.07 \pm$ $1.83 \mathrm{ng} / \mathrm{mL} ; \mathrm{SB}$ and DDGS, respectively). However, SB heifers tended to have less $(P=0.07)$ serum LH concentrations at $60 \mathrm{~h}$ in yr $2(2.18$ vs. $8.55 \pm 1.83 \mathrm{ng} /$ $\mathrm{mL}$; SB and DDGS, respectively) than DDGS heifers. Serum $\mathrm{E}_{2}$ concentration at $60 \mathrm{~h}$ after $\mathrm{PGF}_{2 \alpha}$ was unaffected $(P=0.91)$ by treatment. The percentage of heifers experiencing an LH surge at $48 \mathrm{~h}(P=0.76)$ and $60 \mathrm{~h}(P=0.40)$ was not different between treatment groups (Figure 1). Pregnancy rates were not affected $(P$ $=0.99)$ by dietary treatment ( $88 \%$; Table 2$)$.

Calving data are displayed in Table 4. Neither calf birth date $(P=0.52)$ nor the percentage of heifers giving birth in the first $21 \mathrm{~d}$ of the season $(P=0.84)$ was affected by development diet. Percentage of male calves $(P=0.54)$ and calf birth BW $(P=0.77)$ was similar between dietary treatments. The percentage of heifers requiring assistance at calving was not different $(P=$ $0.20)$. Calf weaning BW $(P=0.22)$ and adjusted $205-\mathrm{d}$ calf BW $(P=0.24)$ were also similar between DDGS and SB heifers. After the second breeding season, 95\% of SB-developed and 91\% of DDGS-developed heifers were pregnant $(P=0.58)$.

\section{DISCUSSION}

In the current study, heifer development supplementation strategy did not influence DF diameter after estrous synchronization. Similar proportions of heifers experienced an LH surge before aspiration with similar $\mathrm{FF} \mathrm{E}_{2}$ and progesterone concentrations. Soybeans are 
Table 2. Effects of supplement on follicle data and pregnancy rates

\begin{tabular}{|c|c|c|c|c|}
\hline \multirow[b]{2}{*}{ Item } & \multicolumn{2}{|c|}{ Treatment $^{1}$} & \multirow[b]{2}{*}{ SEM } & \multirow[b]{2}{*}{$P$-value } \\
\hline & $\mathrm{SB}$ & DDGS & & \\
\hline $\mathrm{n}$ & 50 & 50 & & \\
\hline DF diameter, ${ }^{2} \mathrm{~mm}$ & 12.4 & 12.2 & 0.4 & 0.69 \\
\hline $\mathrm{FF} \mathrm{E}_{2},{ }^{3} \mathrm{pg} / \mathrm{mL}$ & $1,831.6$ & $1,924.3$ & 369.4 & 0.87 \\
\hline $\mathrm{FF} \mathrm{P}_{4},{ }^{4} \mathrm{ng} / \mathrm{mL}$ & 118.1 & 116.8 & 20.1 & 0.96 \\
\hline $\mathrm{E}_{2}$-active, ${ }^{5} \%$ & 76 & 70 & 7 & 0.67 \\
\hline Pregnant, \% & 88 & 88 & 5 & 0.99 \\
\hline
\end{tabular}

a legume and contain phytoestrogens, which have been associated with endocrine disruption in ruminant animals (Adams, 1995). The limited research conducted with SB in heifer development diets suggests an estrogenic feedstuff may affect synchronization rate and the timing of estrus after $\mathrm{PGF}_{2 \alpha}$ in beef heifers (Funston, 2004). However, SB feeding has no detrimental effects on pregnancy rate (Howlett et al., 2003; Funston, 2004; Harris et al., 2008). In the current study, overall pregnancy rates were not affected by supplement.

The high fat content of SB limits their use in cattle diets to 10 to $15 \%$ of total ration DM. Soybeans have elevated linoleic acid content, which has been associated with improved reproductive function in beef heifers (Lammoglia et al., 2000) and mature cows (Wehrman et al., 1991; Ryan et al., 1992). Previous research has demonstrated feeding increased levels of dietary fat results in a larger DF (Lammoglia et al., 1996; De Fries et al., 1998) and is associated with reduced embryonic mortality (Funston, 2004). Subsequent data from Perry et al. (2005) indicate that follicles with a diameter less than $11.5 \mathrm{~mm}$ at ovulation are related to increased em-

Table 3. Serum LH and estradiol $\left(\mathrm{E}_{2}\right)$ concentrations taken at 48 and $60 \mathrm{~h}$ after second $\mathrm{PGF}_{2 \alpha}$ injection

\begin{tabular}{lcccc}
\hline \hline & \multicolumn{2}{c}{ Treatment $^{1}$} & & \\
\cline { 2 - 3 } Item & SB & DDGS & SEM & $P$-value \\
\hline $\mathrm{n}$ & 50 & 50 & & \\
$\mathrm{LH}, \mathrm{ng} / \mathrm{mL}$ & & & & \\
$48 \mathrm{~h}^{2}$ & 2.85 & 2.22 & 0.61 & 0.49 \\
$60 \mathrm{~h}^{3}$ & & & & \\
$\mathrm{Yr} \mathrm{1}$ & 5.83 & 3.07 & 1.83 & 0.35 \\
$\mathrm{Yr} \mathrm{2}$ & 2.18 & 8.55 & 1.83 & 0.07 \\
$\mathrm{E}_{2}, \mathrm{pg} / \mathrm{mL}$ & & & & \\
$48 \mathrm{~h}^{2}$ & 15.97 & 15.88 & 1.57 & 0.97 \\
$60 \mathrm{~h}^{3}$ & 16.56 & 16.32 & 1.50 & 0.91 \\
\hline
\end{tabular}

${ }^{1} \mathrm{SB}=$ supplemented with $1.23 \mathrm{~kg}$ of raw, ground soybeans and 0.40 $\mathrm{kg}$ of corn during postweaning development; DDGS = supplemented with $1.65 \mathrm{~kg}$ of dried distillers grain plus solubles during postweaning development.

${ }^{2}$ Assessed in serum harvested $48 \mathrm{~h}$ after $\mathrm{PGF}_{2 \alpha}$ injection.

${ }^{3}$ Assessed in serum harvested $60 \mathrm{~h}$ after $\mathrm{PGF}_{2 \alpha}$ injection. bryonic mortality. Both supplement sources have increased CP. However, DDGS provides more ruminally undegradable protein, which has been shown to positively affect AI conception rates in heifers (Martin et al., 2007). However, the mechanism by which DDGS improves AI conception has not been elucidated, be it ruminally undegradable protein or a different factor. This experiment cannot directly answer that question because fertility of the oocyte of fertilization was not directly affected by supplementary treatments.

Serum $\mathrm{E}_{2}$ concentrations have been increased in pregnant cows fed elevated levels of fat (rice bran and corn; $5.2 \%$; Lammoglia et al., 1996), but $\mathrm{E}_{2}$ concentrations at $60 \mathrm{~h}$ in the present study were not affected by diet. The preovulatory increase in $\mathrm{DF} \mathrm{E}_{2}$ production declines within $24 \mathrm{~h}$ of ovulation (Alvarez et al., 2000) as granulosa cells become luteinized (Senger, 2003). Aspiration of $\mathrm{DF}$ at $60 \mathrm{~h}$ prevented determination of timing of ovulation. Growth rate of the DF has been increased with increased dietary fat (Lucy et al., 1993). The consequences of these results are uncertain because the

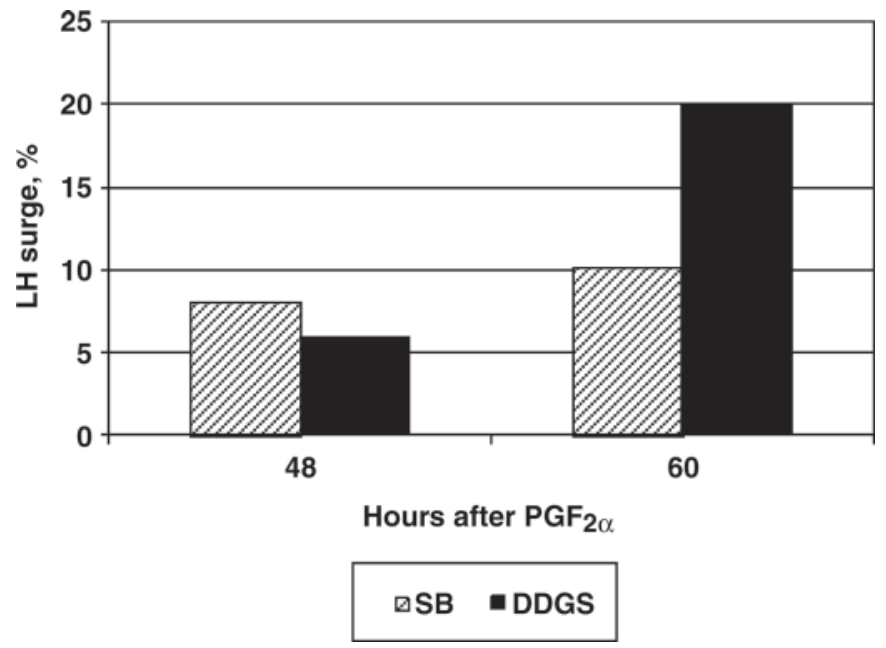

Figure 1. Percentage of heifers experiencing an LH surge at 48 and $60 \mathrm{~h}$ after $\mathrm{PGF}_{2 \alpha}$ injection. No difference $(P \geq 0.40)$ was detected between heifers offered a raw, ground soybean $(\mathrm{SB})$, or dried distillers grain plus solubles (DDGS) supplement. 
Table 4. Effects of supplement on heifer calf production

\begin{tabular}{|c|c|c|c|c|}
\hline \multirow[b]{2}{*}{ Item } & \multicolumn{2}{|c|}{ Treatment $^{1}$} & \multirow[b]{2}{*}{ SEM } & \multirow[b]{2}{*}{$P$-value } \\
\hline & $\mathrm{SB}$ & DDGS & & \\
\hline $\mathrm{n}$ & 41 & 43 & & \\
\hline Calf birth date, Julian d & 154 & 155 & 2 & 0.52 \\
\hline Calf birth BW, kg & 32.0 & 31.8 & 0.5 & 0.77 \\
\hline Calved in first $21 \mathrm{~d}, \%$ & 84 & 86 & 8 & 0.84 \\
\hline Assisted births, \% & 2 & 11 & 6 & 0.20 \\
\hline Sex, \% male & 44 & 53 & 8 & 0.54 \\
\hline Weaning BW, kg & 168 & 162 & 3 & 0.22 \\
\hline 205-d BW, kg & 227 & 220 & 3 & 0.24 \\
\hline Pregnant, second season, $\%$ & 95 & 91 & 4 & 0.58 \\
\hline
\end{tabular}

${ }^{1} \mathrm{SB}=$ supplemented with $1.23 \mathrm{~kg}$ of raw, ground soybeans and $0.40 \mathrm{~kg}$ of corn during postweaning development; DDGS = supplemented with $1.65 \mathrm{~kg}$ of dried distillers grain plus solubles during postweaning development.

collection of reproductive data was delayed by follicle aspiration.

Previous data indicate spring-born heifers fed diets containing SB, after a large percentage attained puberty, exhibited decreased response to synchronization and delayed estrus (Harris et al., 2008). If spring-born heifers consumed diets containing SB and heifers were prepubertal, no difference was seen in reproductive responses. Conception and pregnancy to AI and final pregnancy rates were similar across diets regardless of when SB diets were initiated. In the current experiment, DF characteristics were similar in summer-born heifers supplemented with SB or DDGS during postweaning development, and pregnancy rates did not differ throughout the 2-yr experiment. These data, and previous work, indicate SB and DDGS provided at these levels of supplementation are acceptable feedstuffs for heifers in the prebreeding period.

\section{LITERATURE CITED}

Adams, N. R. 1995. Detection of the effects of phytoestrogens on sheep and cattle. J. Anim. Sci. 73:1509-1515.

Alvarez, P., L. J. Spicer, C. C. Chase Jr., M. E. Payton, T. D. Hamilton, R. E. Stewart, A. C. Hammond, T. A. Olson, and R. P. Wettemann. 2000. Ovarian and endocrine characteristics during an estrous cycle in Angus, Brahman, and Senepol cows in a subtropical environment. J. Anim. Sci. 78:1291-1302.

Cupp, A. S., T. T. Stumpf, N. Kojima, L. A. Werth, M. W. Wolfe, M. S. Roberson, R. J. Kittok, and J. E. Kinder. 1995. Secretion of gonadotrophins change during the luteal phase of the bovine estrous cycle in the absence of corresponding changes in progesterone or 17beta-estradiol. Anim. Reprod. Sci. 37:109-119.

De Fries, C. A., D. A. Neuendorff, and R. D. Randel. 1998. Fat supplementation influences postpartum reproductive performance in Brahman cows. J. Anim. Sci. 76:864-870.

Funston, R. N. 2004. Fat supplementation and reproduction in beef females. J. Anim. Sci. 82(E. Suppl.):E154-E161.

Harris, H. L., A. S. Cupp, A. J. Roberts, and R. N. Funston. 2008. Utilization of soybeans or corn milling co-products in beef heifer development diets. J. Anim. Sci. 86:476-482.

Howlett, C. M., E. S. Vanzant, L. H. Anderson, W. R. Burris, B. G. Fieser, and R. F. Bapst. 2003. Effect of supplemental nutrient source on heifer growth and reproductive performance, and on utilization of corn silage-based diets by beef steers. J. Anim. Sci. 81:2367-2378.
Kojima, F. N., T. T. Stumpf, A. S. Cupp, A. S. Werth, L. A. Roberson, M. W. Wolfe, R. J. Kittok, and J. E. Kinder. 1992. Exogenous progesterone and progestins as used in estrous synchrony regimens do not mimic the corpus luteum in regulation of luteinizing hormone and $17 \beta$-estradiol in circulation of cows. Biol. Reprod. 47:1009-1017.

Lammoglia, M. A., R. A. Bellows, E. E. Grings, J. W. Bergman, S. E. Bellows, R. E. Short, D. M. Hallford, and R. D. Randel. 2000. Effects of dietary fat and sire breed on puberty, weight, and reproductive traits of $\mathrm{F}_{1}$ beef heifers. J. Anim. Sci. 78:2244-2252.

Lammoglia, M. A., S. T. Willard, J. R. Oldham, and R. D. Randel. 1996. Effects of dietary fat and season on steroid hormonal profiles before parturition and on hormonal, cholesterol, triglycerides, follicular patterns, and postpartum reproduction in Brahman cows. J. Anim. Sci. 74:2253-2262.

Lucy, M. C., R. L. De la Sota, C. R. Staples, and W. W. Thatcher. 1993. Ovarian follicular populations in lactating dairy cows treated with recombinant bovine somatotropin (sometribove) or saline and fed diets differing in fat content and energy. J. Dairy Sci. 76:1014-1027.

Martin, J. L., A. S. Cupp, R. J. Rasby, Z. C. Hall, and R. N. Funston. 2007. Utilization of dried distillers grains for developing beef heifers. J. Anim. Sci. 85:2298-2303.

Mattos, R., C. R. Staples, and W. W. Thatcher. 2000. Effects of dietary fatty acids on reproduction in ruminants. Rev. Reprod. 5:38-45.

Melvin, E. J., B. R. Lindsey, J. Quintal-Franco, E. Zanella, K. E. Fike, C. P. Van Tassell, and J. E. Kinder. 1999. Circulating concentrations of estradiol, luteinizing hormone, and folliclestimulating hormone during waves of ovarian follicular development in prepubertal cattle. Biol. Reprod. 60:405-412.

NRC. 1996 (2000 update). Nutrient Requirements of Beef Cattle. 7th ed. Natl. Acad. Press, Washington, DC.

Perry, G. A., M. F. Smith, M. C. Lucy, J. A. Green, T. E. Parks, M. D. MacNeil, A. J. Roberts, and T. W. Geary. 2005. Relationship between follicle size at insemination and pregnancy success. Proc. Natl. Acad. Sci. USA 102:5268-5273.

Roberts, A. J., and S. E. Echternkamp. 2003. Insulin-like growth factor binding proteins in granulosa and thecal cells from bovine ovarian follicles at different stages of development. J. Anim. Sci. 81:2826-2839.

Ryan, D. P., R. A. Spoon, and G. L. Williams. 1992. Ovarian follicular characteristics, embryo recovery, and embryo viability in heifers fed high fat diets and treated with follicle-stimulating hormone. J. Anim. Sci. 70:3505-3513.

Senger, P. L. 2003. Pathways to Pregnancy and Parturition, 2nd ed. Current Conceptions Inc., Moscow, ID.

Stewart, R. E., L. J. Spicer, T. D. Hamilton, B. E. Keefer, L. J. Dawson, G. L. Morgan, and S. E. Echternkamp. 1996. Levels of insulin-like growth factor (IGF) binding proteins, luteinizing 
hormone and IGF-I receptors, and steroids in dominant follicles during the first follicular wave in cattle exhibiting regular estrous cycles. Endocrinology 137:2842-2850.

Wehrman, M. E., T. H. Welsh, and G. L. Williams. 1991. Dietinduced hyperlipidemia in cattle modifies the intrafollicular cholesterol environment, modulates ovarian follicular dynamics and hastens the onset of postpartum luteal activity. Biol. Reprod. 45:514-523.

Wiley, J. S., M. K. Petersen, R. P. Ansotegui, and R. A. Bellows. 1991. Production from first-calf beef heifers fed a maintenance or low level of prepartum nutrition and ruminally undegradable or degradable protein postpartum. J. Anim. Sci. 69:4279 4293.

Williams, G. L., and R. L. Stanko. 2000. Dietary fats as reproductive nutraceuticals in beef cattle. J. Anim. Sci. 77(E. Suppl.):1-12.

Wolfe, P. L., M. W. Wolfe, T. T. Stumpf, J. A. Stotts, M. L. Day, R. J. Kittok, R. K. Johnson, and J. E. Kinder. 1989. Control of luteinizing hormone in postpubertal boars with large testes. J. Anim. Sci. 67:1334-1340. 